\title{
Pemberdayaan Masyarakat dalam Penanaman Tanaman Melati (Jasminum Sambac) Sebagai Larvasida Alami untuk Pencegahan Demam Berdarah Dengue (DBD) di Desa Lebakjabung Kec. Jatirejo Kab. Mojokerto
}

\author{
Acivrida Mega Charisma ${ }^{*}$, Farida Anwari ${ }^{1}$, Elis Anita Farida ${ }^{1}$, dan Khurin In Wahyuni ${ }^{2}$ \\ ${ }^{1}$ Stikes RS Anwar Medika (DIII TLM, Stikes RS Anwar Medika), By Pass Krian Km 33 (Sidoarjo, \\ Indonesia ,61263) \\ ${ }^{2}$ Stikes RS Anwar Medika (S1 Farmasi, Stikes RS Anwar Medika), By Pass Krian Km 33(Sidoarjo, \\ Indonesia ,61263)
}

Correspondence: acie.vrida@gmail.com

Received: 30 Juni 2021 - Revised: 01 Agustus 2021 - Accepted: 16 Agustus 2021

\begin{abstract}
Abstrak. Demam Berdarah Dengue (DBD) masih merupakan salah satu masalah kesehatan masyarakat yang utama di Indonesia. DBD disebabkan oleh salah satu virus dengue berbeda dan ditularkan melalui nyamuk terutama Aedes aegypti dan Aedes albopictus yang ditemukan pada daerah tropis dan sub tropis di antaranya kepulauan Indonesia hingga bagian utara Australia (WHO, 2009). Menurut Kementerian Kesehatan Republik Indonesia dalam sebulan pada bulan Januari-Februari 2016 ditemukan sebanyak 8.487 kasus di Indonesia dengan jumlah kematian sebanyak 108 orang. Golongan terbanyak yang mengalami DBD di Indonesia pada usia 5-14 tahun mencapai 43,44\% dan usia 15-44 tahun mencapai 33,25\%. Kejadian Luar Biasa (KLB) penyakit DBD di Indonesia tersebar pada 11 provinsi. Di Mojokerto Jawa Timur terdapat peningkatan hampir 2.5 kali lipat dibandingkan dengan periode yang sama tahun 2015. Pada tahun 2016, kasus DBD di Sidoarjo hampir mencapai 1\% dari angka kasus nasional sebesar 155.927 (Kompas, 2016). Tingginya angka kasus DBD khususnya di daerah Mojokerto mengindikasikan bahwa pemberantasan DBD masih belum maksimal. Terlebih, metode yang di anggap paling efektif untuk mengendalikan nyamuk vektor demam berdarah adalah dengan cara membunuh jentik- jentiknya. Cara alternatif yang paling aman yaitu dengan cara menggunakan bahan alami yang mudah terurai di alam, termasuk melalui metode penanaman tanaman melati (jasminum sambac) sebagai larvasida alami sehingga tidak mencemari lingkungan serta relatif aman bagi manusia dan ternak peliharaan.
\end{abstract}

Kata kunci: Demam Berdarah Dengue, Larvasida, Melati (jasminum sambac)

Citation Format: Charisma, A.M., Anwari, F., Farida M.M., E.A., \& Wahyuni, K.I.. (2021). Pemberdayaan Masyarakat dalam Penanaman Tanaman Melati (Jasminum Sambac) Sebagai Larvasida Alami Untuk Pencegahan Demam Berdarah Dengue (DBD) di Desa Lebakjabung Kec. Jatirejo Kab. Mojokerto. Prosiding Seminar Nasional Abdimas Ma Chung (SENAM), 420-428. 


\section{PENDAHULUAN}

Demam Berdarah Dengue (DBD) masih merupakan salah satu masalah kesehatan masyarakat yang utama di Indonesia. DBD disebabkan oleh salah satu virus dengue berbeda dan ditularkan melalui nyamuk terutama Aedes aegypti dan Aedes albopictus yang diteukan pada daerah tropis dan sub tropis di antaranya kepulauan Indnesia hingga bagian utara Australia (WHO, 2009). Menurut Kementerian Kesehatan Republik Indonesia dalam sebulan pada bulan Januari-Februari 2016 ditemukan sebanyak 8.487 kasus di Indonesia dengan jumlah kematian sebanyak 108 orang. Golongan terbanyak yang mengalami DBD di Indonesia pada usia 5-14 tahun mencapai 43,44\% dan usia 15-44 tahun mencapai 33,25\%. Kejadian Luar Biasa (KLB) penyakit DBD di Indonesia tersebar pada 11 provinsi. Di Mojokerto Jawa Timur terdapat peningkatan hampir 2.5 kali lipat dibandingkan dengan periode yang sama tahun 2015. Pada tahun 2016, kasus DBD di Sidoarjo hampir mencapai 1\% dari angka kasus nasional sebesar 155.927 (Kompas, 2016). Tingginya angka kasus DBD khususnya di daerah Mojokerto mengindikasikan bahwa pemberantasan DBD masih belum maksimal.

DBD merupakan penyakit infeksi yang dapat menyebabkan kematian. Etiologi penyakit DBD yaitu infeksi virus dengue yang merupakan anggota dari famili Flaviviridae dengan genotype DEN1, DEN2, DEN3, dan DEN4. Virus ini dapat sampai ke tubuh manusia melalui vektor nyamuk Aedes aegypti. Nyamuk ini dapat menularkan penyakit DBD. Setelah terhisap dari darah penderita, virus dengue akan berkembang di dalam kelenjar ludah selama 8-10 hari. Virus ini juga dapat menyebar melalui transfuse maupun transmisi vertikal dari ibu ke anak selama kehamilan (Srinivas, 2016).

Demam Berdarah Dengue (DBD) masih merupakan salah satu masalah kesehatan masyarakat yang utama di Indonesia. DBD disebabkan oleh salah satu virus dengue berbeda dan ditularkan melalui nyamuk terutama Aedes aegypti dan Aedes albopictus yang diteukan pada daerah tropis dan sub tropis di antaranya kepulauan Indonesia hingga bagian utara Australia (WHO, 2009). Menurut Kementerian Kesehatan Republik Indonesia dalam sebulan pada bulan Januari-Februari 2016 ditemukan sebanyak 8.487 kasus di Indonesia dengan jumlah kematian sebanyak 108 orang. Golongan terbanyak yang mengalami DBD di Indonesia pada usia 5-14 tahun mencapai 43,44\% dan usia 15-44 tahun mencapai 33,25\%. Kejadian Luar Biasa (KLB) penyakit DBD di Indonesia tersebar pada 11 provinsi. Di Mojokerto Jawa Timur terdapat peningkatan hampir 2.5 kali lipat dibandingkan dengan 
periode yang sama tahun 2015. Pada tahun 2016, kasus DBD di Mojokerto hampir mencapai 1\% dari angka kasus nasional sebesar 155.927 (Kompas, 2016). Tingginya angka kasus DBD khususnya di daerah Mojokerto mengindikasikan bahwa pemberantasan DBD masih belum maksimal.

Kecamatan Jatirejo memiliki Desa Lebak Jabung dengan batas wilayah desa Bleberan (bagian utara), hutan (bagian timur), desa rejosari (bagian selatan), dan desa Lebak Jabung (bagian barat). Desa Lebak Jabung masih banyak ditemui tumbuhan hijau, perswahan, dan hewan ternak. Jumlah penduduk Lebak Jabung adalah 755 jiwa yang terdiri dari 357 laki-laki dan 398 perempuan. Curah hujan yang dimiliki pun termasuk tinggi dalam bulan februari mencapai $524 \mathrm{~m} 2$ dengan hari hujan selama 21 hari. Kondisi curah hujan yang tinggi dan disertai pemukiman padat akan berdampak pada sanitasi lingkungan karena volume air yang meningkat di selokan-selokan dan banyaknya genangan air di tanah lapang disertai kurangnya kesadaran warga desa. Hal ini akan memicu banyaknya penyakit salah satunya penyakit DBD (demam berdarah).

Desa Lebak Jabung terletak di pemukiman pedesaan yang padat penduduknya. Pemukiman tersebut tidak terlepas dari sanitasi lingkungan karena masih kurangnya kesadaran warga akan kebersihan lingkungan khususnya di musim hujan dimana musim tersebut mulai menunjukkan wabah penyakit salah satunya DBD (demam berdarah). Menurut Kemenkes RI (2020) Jumlah Penderita DBD di Indonesia terus mengalami fluktuasi dari tahun ke tahun, namun seringkali mengalami kenaikan seiring dengan peningkatan laju pertumbuhan penduduk di Indonesia. Data DBD tanggal 30 November 2020 ada 51 penambahan kasus DBD dan 1 penambahan kematian akibat DBD sebanyak 73,35\% atau 377 kabupaten/kota sudah mencapai Incident Rate (IR) kurang dari 49/100.000 penduduk. Proporsi DBD Per Golongan Umur antara lain.

Tabel 1. Jumlah Penderita Demam Berdarah Dengue (DBD):

\begin{tabular}{ll}
\hline Umur (tahun) & Persentase (\%) \\
\hline$<1$ & 3,13 \\
$1-4$ & 14,88 \\
$5-14$ & 33,97 \\
$15-44$ & 37,45 \\
$>44$ & 11,57 \\
\hline
\end{tabular}


Adapun proporsi Kematian DBD Per Golongan Umur antara lain (Kemenkes RI, 2020)

Tabel 2. Angka Kematian Demam Berdarah Dengue

\begin{tabular}{ll}
\hline Umur (tahun) & Persentase (\%) \\
\hline$<1$ & 10,32 \\
$1-4$ & 28,57 \\
$5-14$ & 34,13 \\
$15-44$ & 11,11 \\
$>44$ & 11,57 \\
\hline
\end{tabular}

Peningkatan pengetahuan masyarakat tentang penanggulangan DBD dapat dilakukan dengan promosi kesehatan dengan memberdayakan masyarakat. Upaya dalam mengatasi wabah tersebut, pemerintah biasanya mengadakan kegiatan fogging atau pengasapan di rumah-rumah untuk membasmi nyamuk dan larvanya. Selain itu, warga dihimbau untuk melakukan pengurasan di bak mandi. Namun, kedua upaya tersebut nampaknya masih kurang efisien karena kegiatan fogging dapat menimbulkan efek samping yang diperoleh dari asapnya dan pengurasan bak mandi juga tidak mematikan larva nyamuk karena berpindah tempat di saluran pembuangan air.

Metode yang di anggap paling efektif untuk mengendalikan nyamuk vektor demam berdarah adalah dengan cara membunuh jentik- jentiknya. Cara alternatif yang paling aman yaitu dengan cara menggunakan bahan alami yang mudah terurai di alam sehingga tidak mencemari lingkungan serta relatif aman bagi manusia dan ternak peliharaan.

\section{MASALAH}

Berdasarkan analisis situasi melalui pengamatan dan pengambilan data-data referensi didapatkan permasalahan mengenai cara yang kurang efisien dalam pencegahan terkait di Ds. Lebakjabung, di antaranya yakni kurangnya program pemeriksaan larva berkala dan pendampingan kesehatan keluarga mengenai DBD, Kurangnya kesadaran warga dalam gejala, bahaya, penanganan dan pencegahan $\mathrm{DBD}$, masih terdapat warga yang terkena DBD setiap tahun, Masih menggunakan fogging dalam program desa untuk pencegahan DBD, serta Belum mengetahui solusi alternatif dalam pencegahan DBD selain 3M (menguras, mengubur, dan menutup), yang dapat berdampak pada perkembangan 
vektor nyamuk Aedes aegypti semakin meningkat sehingga dapat meningkatkan transmisi virus.

\section{METODE PELAKSANAAN}

Berdasarkan analisis situasi dan permasalahan yang terjadi pada mitra maka dilakukan metode pelaksanaan melalui pendekatan dan kerjasama dari perangkat desa dan masyarakat dimana tim pengusul pengabdian masyarakat bertindak sebagai tim edukasi dan pendampingan sedangkan warga desa sebagai tim peserta. Dalam kegiatan ini dilakukan beberapa tahapan-tahapan diantaranya:

\section{1) Tahap Persiapan}

Tahapan ini dilakukan dengan membuat tim pengabdian masyarakat yang telah terbentuk oleh dosen STIKES RS Anwar Medika yang kemudian dilakukan beberapa kegiatan yaitu mempersiapkan perijinan pada perangkat desa, kunjungan desa ramah tamah, administrasi, sarana penunjang, posko, jejaring sosial dan berbagai keperluan dalam kegiatan pengabdian masyarakat.

2) Tahap Pelaksanaan

Tahapan pertama dimulai dari sosialisasi mengenai fisiologi nyamuk, gejala, bahaya, dan pencegahan DBD terutama penanaman tanaman herbal sehingga warga desa dapat memahami pentingnya edukasi mengenai DBD dan pencegahan yang sebagai solusi alternatif. Kedua, melakukan briefing dan kerja bakti warga desa setiap seminggu sekali sehingga sanitasi lingkungan semakin baik. Kemudian melakukan penyuluhan tentang pemanfaatan tanaman melati sebagai larvasida alami tersebut. Setelah itu dilakukan penanaman tanaman melati di lahan kosong.

\section{3) Tahap Evaluasi}

Tahapan ini merupakan tahapan terakhir untuk meninjau pelaksanaan pengmas dengan mengacu pada indikator target luaran yaitu hasil penerapan biopredator dalam pencegahan DBD, hasil pemeriksaan larva berkala, jumlah larva nyamuk, dan jumlah kasus DBD yang kemudian dibuat laporan sebagai dokumentasi dan penyuluhan mengenai rencana usaha tnaman herbal yang dibuat lotion anti nyamuk.

\section{HASIL DAN PEMBAHASAN}

Kegiatan yang dilaksanakan pada pengabdian ini terdiri dari program utama berupa Pembuatan Lahan Toga, Pengolahan Toga, Proses Produksi Toga Dan Penggunaan Toga 
terutama pada tanaman melati. Adapun hasil pelaksanaan kegiatan tersebut dapat diuraikan sebagai berikut:

\section{A. Sosialisasi Kegiatan}

Kegiatan ini dilakukan di awal pelaksanaan penyuluhan tentang manfaat tanaman melati sebagai larvasida dan dihadiri oleh masyarkat dan mahasiswa. Pelaksanaannya dilakukan di Kantor Desa Lebak Jabung dan warga dengan pemaparan kegiatan yang akan dilaksanakan selama pelaksanaan kegiatan dengan menerapkan protokol kesehatan.

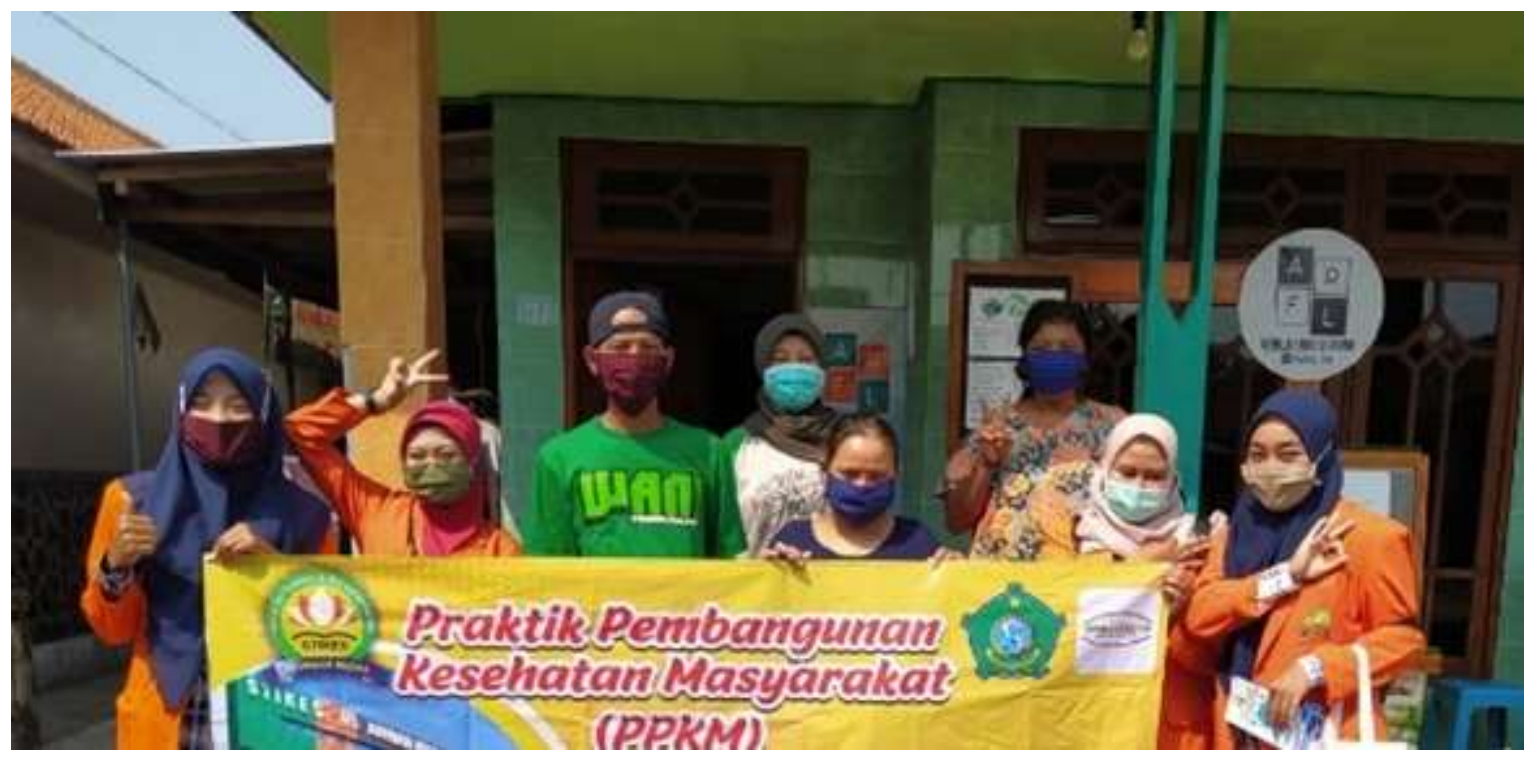

Gambar 1. Kegiatan Penyuluhan Manfaat Tanaman Melati Sebagai Larvasida

\section{B. Penanaman Tanaman Yang Bermanfaat Sebagai Larvasida}

Penanaman di desa lebak jabung setelah dilakukan penyuluhan dilaksanakan penanaman pada tanggal 26 Maret 2021. Penanaman tersebut dilaksanakan oleh warga dan mahasiswa untuk pencegahan Demam Berdarah Dengue.
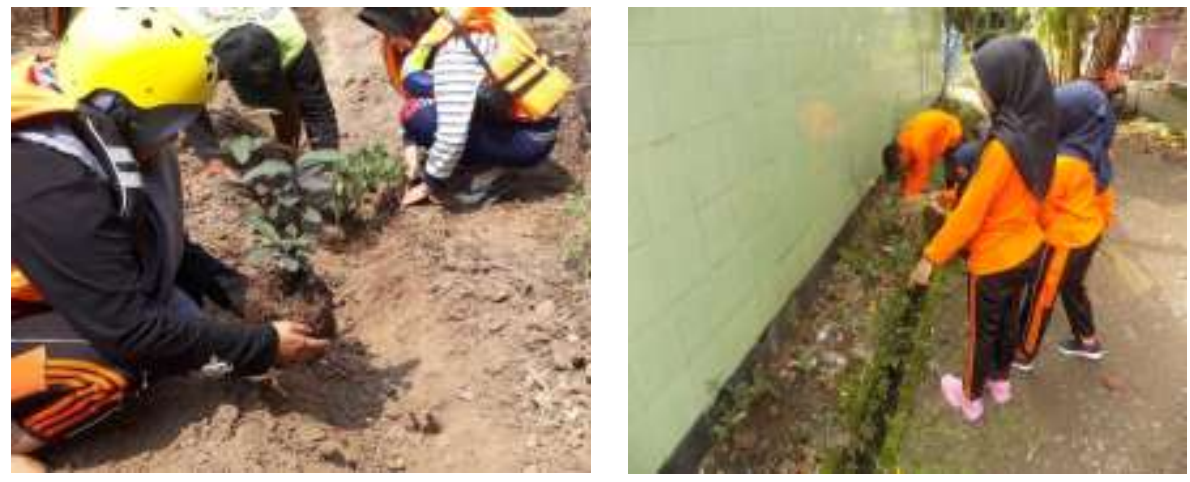

Gambar 2. Penanaman Tanaman Sebagai Larvasida 


\section{Pembuatan Ekstrak Daun Melati untuk Kematian Nyamuk Aedes aygipti berguna Sebagai Larvasida}

Awal kematian larva nyamuk Aedes aegypti dilihata dari seberapa cepat ekstrak daun melati yang direndam untuk membunuh larva nyamuk Aedes aegypti. dan semakin tinggi konsentrasi yang digunakan maka semakin tinggi kematian larva Aedes aegypti yang mati, dengan demikian daun melati bersifat larvasida yang dapat membunuh larva Aedes aegypti. Hal ini disebabkan karena daun melati mempunyai kandungan senyawa aktif golongan flavonoid, Tanin, Saponin, Alkaloid yang fungsi masing-masing dapat membunuh kerusakan pada sistem pernafasan sehingga larva tidak bisa bernafas dan mati. Hasil uji fitokimia daun melati menunjukkan hasil bahwa di dalam daun melati terdapat senyawa yang saponin, alkaloid, tanin, flafonoid positif. Hal ini berarti di dalam daun melati memiliki kandungan saponin, alkaloid, tanin, flafonoid yang sangat tinggi.

Semakin tinggi konsentrasi ekstrak daun melati yang diberikan mengakibatkan jumlah kematian larva Aedes aegypti yang semakin besar pada masing-masing pengulangan dan konsentrasi yang berbeda dan jumlah mati yang bervariasi kemungkinan disebabkan oleh daya resisen dari masing-masing larva uji berbeda terhadap ekstrak daun melati.

Cara masuk insektisida ke dalam tubuh serangga dengan berbagai cara, diantaranya sebagai racun kontak, yang dapat masuk ke dalam kulit tubuh serangga. Racun perut atau mulut dan masuk melalui pencernaan dan yang terakhir dengan fumigant, yang merupakan racun yang masuk melalui pernafafasan serangga. Salah satunya senyawa aktif yang efektif bekerja membunuh larva nyamuk Aedes aegypti yaitu senyawa kandungan Alkaloid.

Kandungan Alkaloid memiliki sifat metabolit terhadap satu atau beberapa asam amino, Aktifitas Alkaloid fisiologinya bersifat racun dan memiliki rasa pahit. Efek toksik lain bias lebih kompleks dn berbahaya terhadap insekta, yaitu menggangu aktivitas tirosin yang merupakan enzim essensial untuk pengerasan kutikula insekta. Alkaloid merupakan komponen aktif yang bekerja di saraf, selain itu juga dapat menyebabkan gangguan pencernaan karena alkaloid dapat bertindak sebagai racun melalui mulut larva. Selain dari Flavonoid juga disebabkan karena kandungan saponin, umur larva merupakan faktor yang sangat berpengaruh terhadap daya tahan larva terhadap pajanan insektisida. Oleh karena itu 
pemilihan larva merupakan hal yang sangat penting dalam penelitian. Kisaran umur larva yang dapat digunakan dalam penelitian adalah rentang usia 3-4 hari atau instar III awal. Pada instar III tubuh larva telah berbentuk dengan baik. Apabila menggunakan larva dibawah instar II, organ tubuh larva belum terbentuk belum sempurna dan keadaan fisik larva masih sangat lemah sehingga akan mempermudah terjadinya kematian larva (Hadi dan Soviana, 2011).

Jumlah larva yang digunakan dalam uji suatu insektisida berhubungan dengan keakuratan data hasil penelitian. Jumlah sampel yang terlalu sedikit akan menghasilkan presentase kematian larva yang tinggi. Sehingga dapat meningkatkan resiko terjadinya bias data hasil penelitian. Sementara jumlah larva yang terlalu banyak mengakibatkan peningkatan kematian akibat persaingan hidup antar larva dalam wadah

Dari pelaksanaan pengabdian kepada masyarakat dapat menerapkan program pencegahan $3 \mathrm{M}$ dengan metode penanaman tanaman melati sebagai larvasida sehingga kedepan dapat membuka keirausahaan masyarakat untuk budidaya tanaman melati untuk menunjang pemberantasan nyamuk Aedes aegipty (Charisma, 2019).

\section{KESIMPULAN}

Setelah kegiatan dilaksanakan, dapat ditarik kesimpulan bahwa pelatihan dan penyuluhan tanaman obat yaitu tanaman melati sebagai larvasida dapat meningkatkan pengetahuan tata cara penanaman tanaman obat yang baik, serta terwujudnya pemberdayaan dan peningkatan pengetahuan bagi peserta pelatihan terkait dengan penanaman dan pemanfaatan tanaman melati. Serta sebagai saran untuk peneliti selanjutnya agar menambahkan tempat lain sebagai objek, dan materi pelatihan manajemen pemasaran agar promosi produk dapat dilakukan sebagai nilai jual produk.

\section{UCAPAN TERIMA KASIH}

Tim Pengabdian Kepada Masyarakat mengucapkan terima kasih atas bantuan dari STIKES RS ANWAR MEDIKA dan pemerintah Desa Lebakjabung karena telah membantu proses penelitian ini berjalan lancar hingga selesai.

\section{DAFTAR PUSTAKA}

Charisma, AM, Elis AF, dan Farida A., (2019). Penerapan Biopredator sebagai Penurunan Jumlah Larva Nyamuk Aedes aegypti untuk Pencegahan Wabah DBD (Demam Berdarah Dengue) Di Dusun Semawut Desa Balongbendo Kab. Sidoarjo.

Hadi, Soviana, (2010). Parasitologi Kedokteran , Edisi Ke-2, Gadjah Mada University 
Press, Yogyakarta.

Kemenkes RI. (2020). Data Kasus Terbaru DBD di Indonesia. Diakses melalui https://sehatnegeriku.kemkes.go.id/baca/umum/20201203/2335899/data-kasusterbaru-dbd-indonesia/ pada tanggal 13 Juli 2021.

Kompas, 2016. Kasus di Sidoarjo Melonjak Lebih dari Dua Kali Lipat. Kompas: Sidoarjo.

Srinivas, Vaddadi.2015. Dengue Fever: Review Article. $J$ of Evolution of Med and Dent Sci/ eISSN (4): 2278-4802.

WHO. 2009. Dengue Guidelines for Diagnosis, Treatment, Prevention and Control (PDF). Geneva: World Health Organization. ISBN 9241547871. 